\title{
Chest Computed Tomography for Screening Suspected Cases of SARS-CoV-2 Infection in Trauma Patients
}

\author{
Camila R Guetter ${ }^{1} \odot$, Rebeca T Iurkiewiecz ${ }^{2} \odot$, Matheus S Evangelista $^{3} \odot$, Gabriel M Nogueira ${ }^{4}$, Leonardo K Rafael $^{5}$, \\ Silvania K Pimentel ${ }^{6}{ }^{\bullet}$, Fabio Henrique De Carvalho ${ }^{7}{ }^{\circ}$
}

\begin{abstract}
Aim: To describe an institution's experience with the implementation of a chest computed tomography (CT) protocol to screen suspected cases of COVID-19 among trauma patients.

Materials and methods: This is a longitudinal observational study, which was carried during 67 days of the COVID-19 pandemic. We included all adult trauma patients, who underwent chest CT at admission. According to the screening protocol, all patients with moderate/severe trauma requiring hospitalization and/or surgery underwent chest CT. Imaging suggestive of COVID-19 led to activation of infection control protocols in the operating room and during hospitalization. We performed univariate analysis to compare patients according to indication of chest CT (trauma mechanism or COVID-19 protocol).

Results: We included 352 patients. Mean age was 44.95 years, $74.64 \%$ were male. Most patients ( $72.16 \%)$ underwent chest CT due to mechanism of trauma. Nine (2.35\%) patients had CT scans suggestive of COVID-19, seven of which were performed based on the screening protocol. Among these nine patients, three were symptomatic for COVID-19 and one had laboratory confirmation of SARS-CoV-2 infection. With respect to the patient subgroups according to CT scan indication, difference was observed regarding body injury location $(p=0.000)$, presence of COVID-19 symptoms $(p=0.014)$ and prevalence of altered imaging findings $(p=0.000)$.

Conclusion: Although further validation for this purpose is needed, chest CT has shown to be an important tool for screening suspected cases of COVID-19 in the context of trauma surgery.

Clinical significance: Improvement of COVID-19 screening in trauma settings can allow better allocation of resources and minimize viral transmission. Keywords: Computed tomography, Coronavirus infections, COVID-19, Observational study, Protocols, Surgery, Trauma surgery care.
\end{abstract}

\section{Resumo}

Objetivo: Descrever a experiência de uma instituição na implementação de protocolo de rastreio de COVID-19 com tomografia computadorizada (TC) de tórax para pacientes vítimas de trauma.

Materiais e métodos: Estudo observacional longitudinal. Foram incluídos todos os pacientes adultos, vítimas de trauma, atendidos durante 67 dias na pandemia de COVID-19, e que realizaram TC de tórax na admissão. Pelo protocolo, pacientes com trauma moderado/grave com necessidade de internamento/cirurgia realizaram TC de tórax. Casos com TC sugestiva de COVID-19 foram manejados como infectados, ativando protocolos de controle de infecção no centro cirúrgico e no internamento. Análise univariada foi realizada para comparar subgrupos de pacientes conforme indicação da TC de tórax (mecanismo de trauma ou protocolo COVID-19).

Resultados: Foram incluídos 352 pacientes. A média etária foi 44,95 anos e $74,64 \%$ eram masculinos. A maioria dos pacientes (72,16\%) realizou TC de tórax devido ao mecanismo de trauma. Nove pacientes (2,35\%) apresentaram tomografias sugestivas de COVID-19, sendo sete destas realizadas pelo protocolo de rastreio. Desses nove pacientes, três eram sintomáticos e apenas um apresentou confirmação laboratorial de SARS-CoV-2. Em relação aos subgrupos de indicação da TC, houve diferença em relação à região corporal do trauma $(p=0,000)$, presença de sintomas $(p=0,014)$ e presença de alterações de imagem $(p=0,000)$.

Conclusão: ATC de tórax, apesar de ainda beneficiar de mais validação, mostra ser uma ferramenta importante para triagem de COVID-19 no trauma. Significado clínico: Melhoras no rastreio de casos suspeitos de COVID-19 pode permitir melhor alocação de recursos e minimização de transmissão viral no contexto do trauma.

Palavras-chave: Cirurgia, COVID-19, Estudo observacional, Infecções por coronavirus, Protocolos, Tomografia, Traumatologia.

Panamerican Journal of Trauma, Critical Care \& Emergency Surgery (2021): 10.5005/jp-journals-10030-1358

\section{INTRODUCTION}

On March 11, 2020, the World Health Organization (WHO) characterized COVID-19 as a pandemic. ${ }^{1}$ Most patients infected with SARS-CoV-2, the etiologic agent of COVID-19, may initially be oligosymptomatic, even those individuals presenting the pulmonary form of the disease. As a result, many trauma patients can arrive at the emergency department without signs or symptoms compatible with COVID-19 and, even so, be active agents for disease transmission. ${ }^{2,3}$

Pandemics generate socioeconomic crises and may overload the healthcare system, similarly to what might be seen in periods of war. This leads to the need for adjustments in the previously established forms of care, aiming at the rational use of material, physical, and human resources so as to reserve them for a future
1Johns Hopkins Bloomberg School of Public Health, Baltimore, Maryland, United States

2,3,6,7 Department of Surgery, Hospital Do Trabalhador, Curitiba, Brazil

${ }^{4,5}$ School of Medicine, Universidade Federal Do Paraná, Curitiba, Brazil

Corresponding Author: Camila R Guetter, Johns Hopkins Bloomberg School of Public Health, Baltimore, Maryland, United States, e-mail: camilaguetter@gmail.com

How to cite this article: Guetter CR, lurkiewiecz RT, Evangelista MS, et al. Chest Computed Tomography for Screening Suspected Cases of SARS-CoV-2 Infection in Trauma Patients. Panam J Trauma Crit Care Emerg Surg 2021;10(3):101-106.

Source of support: Nil

Conflict of interest: None

() The Author(s). 2021 Open Access This article is distributed under the terms of the Creative Commons Attribution 4.0 International License (https://creativecommons. org/licenses/by-nc/4.0/), which permits unrestricted use, distribution, and non-commercial reproduction in any medium, provided you give appropriate credit to the original author(s) and the source, provide a link to the Creative Commons license, and indicate if changes were made. The Creative Commons Public Domain Dedication waiver (http://creativecommons.org/publicdomain/zero/1.0/) applies to the data made available in this article, unless otherwise stated. 
of potential scarcity. Previously established guidelines, such as indication criteria for computed tomography (CT) scans in the trauma care setting, can be expanded aiming at diagnosis of SARS-CoV-2 infections. Early diagnosis of COVID-19 allows for adequate precaution measures to be taken to avoid transmission to other patients and healthcare professionals. ${ }^{2,4}$

Before COVID-19 was declared as a global pandemic, we were already living in the midst of another endemic, trauma. Approximately 6 million people, from different age and socioeconomic groups, die every year from unintentional injuries and violence around the world. ${ }^{5}$ External causes represent the main causes of death in the first four decades of life, being responsible for the loss of more years of productive life than heart disease and cancer. ${ }^{6}$ It is estimated that more than nine people die every minute from injuries to internal organs or violence, reaching a total of approximately 5 million deaths every year from these causes. ${ }^{5}$

The emergence of the pandemic prompted many countries to adopt public policies of social isolation in order to reduce viral transmission. This led to a decrease in mobility of individuals and a consequent reduction in the number of accidents involving transportation vehicles or work-related trauma. However, it has been observed that the number of trauma injuries inside homes and those caused by interpersonal violence have remained stable or even increased. ${ }^{7-9}$

Therefore, the combination of continuously high rates of trauma injury and a pandemic infection that is often asymptomatic results in an urgent need for changes in the way we care for trauma patients. These include early diagnosis of asymptomatic patients for COVID-19 and measures to reduce viral transmission to other patients and health professionals. Many emergency services are establishing measures such as expanding indication criteria for chest $\mathrm{CT}$ among trauma patients, based on protocols by countries that faced the pandemic earlier. ${ }^{2,4,10-12}$ These measures require constant analysis for adjustments and improvements throughout the pandemic.

This study aimed to describe our experience with the implementation of chest CT as a protocol for screening suspected cases of SARS-CoV-2 infection in trauma patients during the COVID-19 pandemic.

\section{Materials and Methods}

\section{Study Design, Inclusion, and Exclusion Criteria}

This is a longitudinal observational study, approved by the Human Research Ethics Committee CEPSH-SESA/HT (CAAE 306,37720.4.0000.0008).

Were included in the study all adult trauma patients (18 years old and over), who received trauma care at Hospital do Trabalhador in Curitiba, Brazil, between March 11, 2020 and May 21, 2020. All patients included in the study underwent chest $C T$ at time of admission to the emergency department. The Hospital do Trabalhador is a state reference trauma center and is also currently one of the state reference centers for the care of patients with SARS-CoV-2 infection during the pandemic. The starting date for the study period was based on the date COVID-19 was first considered a pandemic by the WHO. Patients who were transferred to another hospital during hospitalization were excluded from the study.

Protocol with Chest Computed Tomography and RT-PCR Testing for SARS-CoV-2

The protocol was applied to those patients with moderate to severe trauma injuries and with need for hospitalization and/or surgery. All patients with these criteria underwent chest $\mathrm{CT}$, regardless of the body part where impact or injury occurred. Imaging was performed on a Bright Speed $G^{R}$ 16-channel equipment. In this study, patients were submitted to noncontrast CT. Scanning parameters included tube voltage of $120 \mathrm{kV}$, tube current $300 \mathrm{~mA}$, and slice thickness of $1.25 \mathrm{~mm}$. The tomography room at the institution where this study was conducted is connected to the initial trauma care room, with no need for patient transportation. Thus, there is no significant impact on the time to perform the exam as well as time to start treatment of critically ill patients. Previously to this protocol, we had already expanded the use of tomography at the institution, even for patients with penetrating trauma lesions, without impact on clinical and surgical outcomes of these patients. ${ }^{13}$

Patients with evidence of ground-glass pulmonary opacities and/or consolidations, with predominantly peripheral distribution, ${ }^{14}$ were considered suspected cases for COVID-19 and managed as infected, activating specific protocols in the operating room and for respiratory isolation. Examples of tomographic images obtained in this study are included for reference (Figs 1 and 2).

\section{Data Collection}

Data collection for this study was based on review of electronic medical records. Variables analyzed included patient demographic

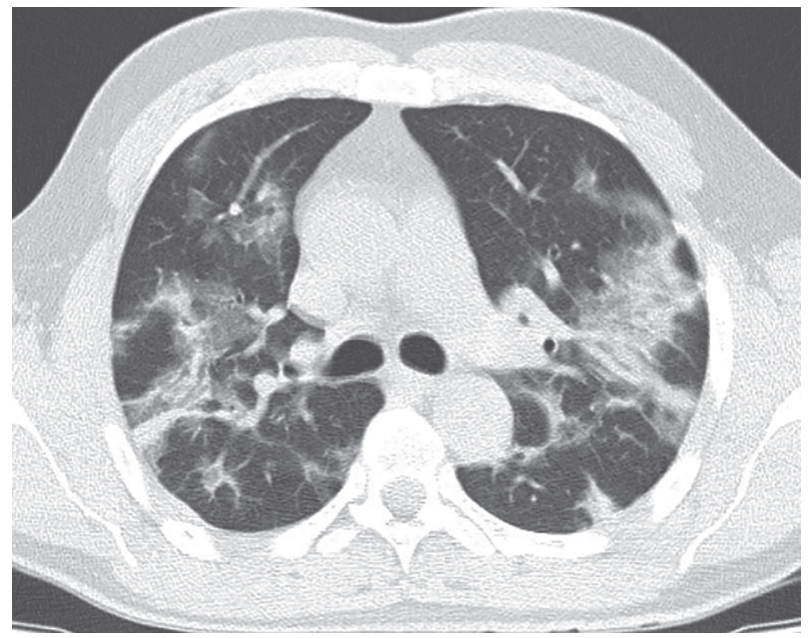

Fig. 1: Representative chest computed tomography image, axial view

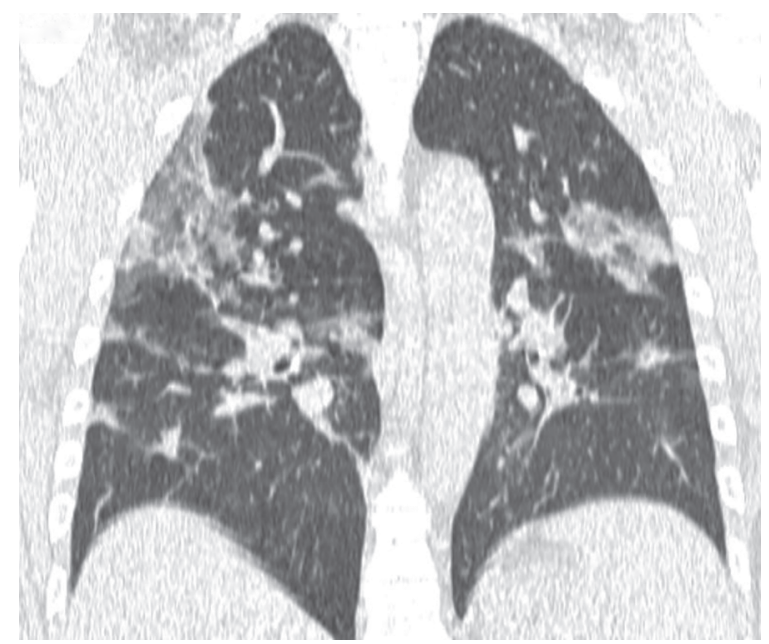

Fig. 2: Representative chest computed tomography image, coronal view 
characteristics, mechanism of trauma, and body location of the impact or injury. Data on admission and hospital stay were also analyzed, including length of hospital stay and in-hospital mortality. We also analyzed the presence of symptoms suggestive of SARS-CoV-2 infection at admission, the reason for performing chest $C T$, findings observed on imaging, and the result of RT-PCR tests for SARS-CoV-2 when performed.

\section{Statistical Analysis}

Measures of central tendency and dispersion were expressed as means and standard deviation for continuous variables, and in absolute and relative frequencies for categorical and ordinal variables. We performed Shapiro-Wilk tests and generation of histograms to analyze the data distribution.

Univariate analysis was performed comparing two subgroups of patients by indication for chest CT (trauma mechanism vs COVID-19 screening protocol). Analysis was conducted using $T$ test for normal continuous dependent variables, MannWhitney test for non-normal continuous dependent variables, and Chi-Square for categorical dependent variables. The level of significance was established at 5\% for this study. Statistical analysis was performed using the statistical software Stata version 14.2

\section{Results}

Data were collected from a 67-dayperiod. During this time, a total of 5,017 patients were admitted to the institution's emergency department, 2,380 of who arrived by ambulance transportation. Among these, 352 patients were included in the study, according to the inclusion criteria previously discussed (Table 1). Patient mean age was $44.95 \pm 18.31$ years old, and $262(74.64 \%)$ were male. Most patients (79.2\%) did not have previous comorbidities.

In the sample analyzed, 301 (86\%) patients suffered blunt trauma, and 193 (59.38\%) patients had trauma involving the thoracic region (isolated or combined with trauma located in other body regions).

Thirty-eight (10.8\%) patients had symptoms suggestive of COVID-19, including runny nose, cough, dyspnea, and fever. All patients included in this study underwent chest $\mathrm{CT}$, with $72.16 \%$ having done the exam due to the trauma mechanism and possible associated injuries, while the other $27.84 \%$ were performed due to the ongoing screening protocol for SARS-CoV-2 infections at the institution (Table 2).

Imaging suggestive of SARS-CoV-2 infections on chest CT was observed in nine (2.56\%) patients, seven of which were performed due to the COVID-19 screening protocol (Table 3). Of these nine exams suggestive of COVID-19, three patients had symptoms compatible with SARS-CoV-2 infection, while the others were asymptomatic. The average peripheral oxygen saturation in this group of patients was $94.75 \pm 5.01 \%$. Of the nine patients in question, only one tested positive for RT-PCR for SARS-CoV-2, and this patient was asymptomatic.

Regarding morbidity and mortality outcomes (Table 4), 47.16\% of the patients in the sample did not require hospitalization, receiving hospital discharge after medication, exams, and observation. Surgical procedures during hospital stay were performed in 121 (34.38\%) patients, four of which presented tomographic changes suggestive of SARS-CoV-2 infection. The overall length of hospital stay was $5.19 \pm 10.99$ days.

The great majority of patients $(90.34 \%)$ did not present complications during hospitalization. Among the 34 patients
Table 1: Patient demographic information

\begin{tabular}{lc}
\hline & Total $(n=352)$ \\
\hline Male gender [n (\%)] & $262(74.64)$ \\
Age (mean, SD) & $44.95(18.31)$ \\
Comorbidities [n (\%)] & \\
None & $278(79.2)$ \\
One & $43(12.25)$ \\
Two or more & $30(8.55)$ \\
Mechanism of trauma [n (\%)] & \\
Penetrating & $49(14)$ \\
Blunt & $301(86)$ \\
Body region where trauma occurred [n (\%)] & \\
Thoracic trauma present & $193(59.38)$ \\
Without thoracic trauma & $132(40.62)$ \\
Vitals signs at time of admission (mean, SD) & \\
Heart rate (bpm) & $87.42(17.77)$ \\
Mean arterial pressure (mm Hg) & $95.46(17.97)$ \\
Peripheral oxygen saturation (\%) & $96.79(2.79)$ \\
\hline
\end{tabular}

Table 2: Symptoms and laboratory exams for SARS-CoV-2

\begin{tabular}{lc}
\hline & Total $(n=352)$ \\
\hline Symptoms suggestive of COVID-19 [n (\%)] & $38(10.8)$ \\
Reason for chest CT [n (\%)] & $245(72.16)$ \\
Mechanism of trauma & $98(27.84)$ \\
COVID-19 screening protocol & \\
Findings in chest CT [n (\%)] & $104(29.55)$ \\
Findings related to mechanism of trauma & $9(2.56)$ \\
Findings suggestive of COVID-19 infection & $239(67.9)$ \\
No findings related to mechanism of trauma or & \\
COVID-19 infection & \\
Results of RT-PCR for SARS-CoV-2 [n (\%)] & $7(87.5)$ \\
Negative & $1(12.5)$ \\
Positive &
\end{tabular}

that had complications, a total of 11 (3.12\% of the total sample) progressed to in-hospital death.

Finally, when analyzing indication of chest CT (trauma mechanism versus COVID-19 screening protocol), the groups were not different in relation to sex, age, comorbidities, mechanism of trauma, or vital signs at admission (Table 5). However, a difference was observed between groups regarding the body region where trauma occurred $(p=0.000)$ and the presence of symptoms suggestive of COVID-19 $(p=0.014)$. Patients with thoracic trauma were in almost all cases (98.45\%) submitted to chest CT due to the mechanism of trauma, while those with lesions in other body regions most often underwent chest CT for COVID-19 screening (65.15\%). Regarding the presence of symptoms suggestive of COVID-19, asymptomatic patients underwent tomography due to trauma mechanism in $74.20 \%$ of the cases. Among symptomatic patients, the trauma mechanism still remained as the main indication for chest tomography, however in only $55.26 \%$ of the cases.

In addition, a difference was seen between the two different $C T$ indication groups in relation to the imaging findings $(p=0.000)$. Most patients with tomographic changes compatible 
Table 3: Patients with findings on chest CT suggestive of COVID-19 infection

\begin{tabular}{|c|c|c|c|c|c|c|c|c|c|c|}
\hline Patient & Gender & Age & $\begin{array}{l}\text { Mechanism } \\
\text { of trauma }\end{array}$ & $\begin{array}{c}\text { Previous } \\
\text { comorbidities }\end{array}$ & $\begin{array}{c}\text { Symptoms } \\
\text { suspected } \\
\text { for COVID-19 }\end{array}$ & $\begin{array}{l}\text { Reason for } \\
\text { chest CT }\end{array}$ & $\begin{array}{l}\text { Findings in } \\
\text { chest } C T\end{array}$ & Outcome & $\begin{array}{l}\text { Hospital } \\
\text { length } \\
\text { of stay } \\
\text { (days) }\end{array}$ & $\begin{array}{c}R T-P C R \\
\text { for SARS- } \\
\text { Cov-2 }\end{array}$ \\
\hline 1 & $M$ & 24 & $\begin{array}{l}\text { Blunt on } \\
\text { lower } \\
\text { extremities }\end{array}$ & - & - & $\begin{array}{l}\text { COVID-19 } \\
\text { protocol }\end{array}$ & $\begin{array}{c}\text { Ground-glass } \\
\text { opacities }\end{array}$ & $\begin{array}{l}\text { Hospital stay with } \\
\text { surgical procedure } \\
\text { and complications; } \\
\text { hospital discharge }\end{array}$ & 8 & \\
\hline 2 & M & 24 & $\begin{array}{l}\text { Blunt on } \\
\text { head, } \\
\text { abdomen, } \\
\text { upper, and } \\
\text { lower } \\
\text { extremities }\end{array}$ & - & - & $\begin{array}{l}\text { COVID-19 } \\
\text { protocol }\end{array}$ & $\begin{array}{c}\text { Ground-glass } \\
\text { opacities }\end{array}$ & Hospital discharge & 0 & \\
\hline 3 & $M$ & 56 & $\begin{array}{l}\text { Blunt on } \\
\text { thorax }\end{array}$ & - & - & $\begin{array}{l}\text { Mechanism } \\
\text { of trauma }\end{array}$ & $\begin{array}{l}\text { Ground-glass } \\
\text { opacities, rib } \\
\text { fracture, } \\
\text { pneumothorax }\end{array}$ & $\begin{array}{l}\text { Hospital stay with } \\
\text { surgical procedure; } \\
\text { no complications; } \\
\text { hospital discharge }\end{array}$ & 5 & Positive \\
\hline 4 & M & 74 & $\begin{array}{c}\text { Blunt on } \\
\text { head }\end{array}$ & $\begin{array}{l}\text { Hypertension, } \\
\text { diabetes, } \\
\text { Alzheimer's } \\
\text { Disease }\end{array}$ & $\begin{array}{l}\text { Cough and } \\
\text { fever }\end{array}$ & $\begin{array}{l}\text { COVID-19 } \\
\text { protocol }\end{array}$ & $\begin{array}{c}\text { Ground-glass } \\
\text { opacities }\end{array}$ & $\begin{array}{l}\text { Hospital stay with } \\
\text { surgical procedure } \\
\text { and complications; } \\
\text { hospital discharge }\end{array}$ & 23 & Negative \\
\hline 5 & M & 44 & $\begin{array}{l}\text { Blunt on } \\
\text { thorax and } \\
\text { abdomen }\end{array}$ & - & - & $\begin{array}{l}\text { Mechanism } \\
\text { of trauma }\end{array}$ & $\begin{array}{l}\text { Ground-glass } \\
\text { opacities }\end{array}$ & Hospital discharge & 0 & Negative \\
\hline 6 & M & 61 & $\begin{array}{l}\text { Blunt on } \\
\text { head }\end{array}$ & Hypertension & Cough & $\begin{array}{l}\text { COVID-19 } \\
\text { protocol }\end{array}$ & $\begin{array}{l}\text { Ground-glass } \\
\text { opacities }\end{array}$ & Hospital discharge & 0 & Negative \\
\hline 7 & $M$ & 34 & $\begin{array}{l}\text { Penetrating } \\
\text { on head }\end{array}$ & - & Cough & $\begin{array}{l}\text { COVID-19 } \\
\text { protocol }\end{array}$ & $\begin{array}{c}\text { Ground-glass } \\
\text { opacities }\end{array}$ & $\begin{array}{l}\text { Hospital stay } \\
\text { without surgical } \\
\text { procedure or } \\
\text { complications; } \\
\text { hospital discharge }\end{array}$ & 4 & \\
\hline 8 & M & 38 & $\begin{array}{c}\text { Blunt on } \\
\text { head }\end{array}$ & Schizophrenia & - & $\begin{array}{l}\text { COVID-19 } \\
\text { protocol }\end{array}$ & $\begin{array}{c}\text { Ground-glass } \\
\text { opacities }\end{array}$ & $\begin{array}{l}\text { Hospital stay with } \\
\text { surgical procedure; } \\
\text { no complications; } \\
\text { hospital discharge }\end{array}$ & 14 & Negative \\
\hline 9 & M & 53 & $\begin{array}{l}\text { Blunt on } \\
\text { head and } \\
\text { upper } \\
\text { extremities }\end{array}$ & $\begin{array}{c}\text { Alcohol abuse } \\
\text { disorder }\end{array}$ & - & $\begin{array}{l}\text { COVID-19 } \\
\text { protocol }\end{array}$ & $\begin{array}{c}\text { Ground-glass } \\
\text { opacities }\end{array}$ & $\begin{array}{l}\text { Hospital stay with } \\
\text { surgical procedure; } \\
\text { no complications; } \\
\text { hospital discharge }\end{array}$ & 8 & Negative \\
\hline
\end{tabular}

M, Male

Table 4: Patient outcomes

\begin{tabular}{lc}
\hline & Total $(n=352)$ \\
\hline Medical procedures $n(\%)$ & \\
Medication and short-term observation only & $166(47.16)$ \\
Hospital admission with surgical procedure & $121(34.38)$ \\
Hospital admission without surgical procedure & $65(18.47)$ \\
Length of hospital stay in days (mean, SD) & $5.19(10.99)$ \\
$\begin{array}{l}\text { Clinical outcome } n(\%) \\
\text { No in-hospital complications; hospital dis- }\end{array}$ & $318(90.34)$ \\
charge & $17(4.83)$ \\
$\begin{array}{l}\text { In-hospital complications; hospital discharge } \\
\text { Death }\end{array}$ & $11(3.12)$ \\
In-hospital complications; still an in-patient to & $6(1.7)$ \\
this date & \\
\hline
\end{tabular}

with the mechanism of trauma (95.19\%) underwent imaging due to the trauma itself. Patients with findings suggestive of COVID-19 on chest CT, in turn, underwent imagining due to the COVID-19 screening protocol in $77.78 \%$ of cases.

\section{Discussion}

After the WHO declared the COVID-19 pandemic on March 11, $2020,{ }^{1}$ our institution made adjustments to protocols for the care of trauma patients. In addition, the institution has become a reference center for the care of patients with suspected or confirmed severe acute respiratory syndrome related to COVID-19.

Among these protocols, we adopted the use of chest CT for every trauma patient with the possibility of hospitalization and/or surgery. This protocol aimed to increase early diagnosis of asymptomatic COVID-19 cases, leading to targeted and efficient measures to minimize transmission to healthcare professionals and other patients. 
Table 5: Univariate analysis on subgroups according to reason for chest CT

\begin{tabular}{|c|c|c|c|}
\hline & $\begin{array}{l}\text { Chest CT due to mechanism } \\
\text { of trauma }(n=254)\end{array}$ & $\begin{array}{l}\text { hest CT due to COVID-19 } \\
\text { screening protocol } \\
\qquad(n=98)\end{array}$ & $p$ \\
\hline Male gender [n(\%)] & $194(74.05)$ & $68(25.95)$ & 0.159 \\
\hline Age (mean, SD) & $44.30(1.13)$ & $46.59(1.96)$ & 0.4102 \\
\hline Comorbidities [n (\%)] & & & 0.396 \\
\hline None & $205(73.74)$ & $73(26.26)$ & \\
\hline One & $28(65.12)$ & $15(34.88)$ & \\
\hline Two or more & $20(66.67)$ & $10(33.33)$ & \\
\hline Mechanism of trauma [n (\%)] & & & 0.847 \\
\hline Penetrating & $35(71.43)$ & $14(28.57)$ & \\
\hline Blunt & $219(72.76)$ & $82(27.24)$ & \\
\hline Body region where trauma occurred [n (\%)] & & & $0.000^{\mathrm{a}}$ \\
\hline Thoracic trauma present & $190(98.45)$ & $3(1.55)$ & \\
\hline Without thoracic trauma & $46(34.85)$ & $86(65.15)$ & \\
\hline \multicolumn{4}{|l|}{ Vitals signs at time of admission (mean, SD) } \\
\hline Heart rate (bpm) & $87.70(1.15)$ & $86.7(2.02)$ & 0.4515 \\
\hline Mean arterial pressure (mmHg) & $94.69(1.18)$ & $97.36(1.99)$ & 0.3193 \\
\hline Peripheral oxygen saturation (\%) & $96.77(0.18)$ & $96.84(0.30)$ & 0.8296 \\
\hline Symptoms suggestive of COVID-19 [n (\%)] & $21(55.26)$ & $17(44.74)$ & $0.014^{\mathrm{a}}$ \\
\hline Findings in chest CT $[n(\%)]$ & & & $0.000^{\mathrm{a}}$ \\
\hline Findings related to mechanism of trauma & 99 (95.19) & $5(4.81)$ & \\
\hline Findings suggestive of COVID-19 infection & $2(22.22)$ & $7(77.78)$ & \\
\hline $\begin{array}{l}\text { No findings related to mechanism of trauma or COVID-19 } \\
\text { infection }\end{array}$ & $153(64.02)$ & $86(35.98)$ & \\
\hline Results of RT-PCR for SARS-CoV-2 [n(\%)] & & & 0.064 \\
\hline Negative & $1(14.29)$ & $6(85.71)$ & \\
\hline Positive & $1(100)$ & $0(0)$ & \\
\hline Medical procedures [n (\%)] & & & 0.247 \\
\hline Medication and short-term observation only & $126(75.90)$ & $40(24.10)$ & \\
\hline Hospital admission with surgical procedure & $81(66.94)$ & $40(33.06)$ & \\
\hline Hospital admission without surgical procedure & $47(72.31)$ & $18(27.69)$ & \\
\hline Length of hospital stay in days (mean, SD) & $5.62(0.75)$ & $4.09(0.77)$ & 0.243 \\
\hline Clinical outcome $[n(\%)]$ & & & 0.221 \\
\hline No in-hospital complications; hospital discharge & $232(72.96)$ & $86(27.04)$ & \\
\hline In-hospital complications; hospital discharge & $12(70.59)$ & $5(29.41)$ & \\
\hline Death & $5(45.45)$ & $6(54.55)$ & \\
\hline In-hospital complications; still an in-patient to this date & $5(83.33)$ & $1(16.67)$ & \\
\hline
\end{tabular}

a $p<0.005$

The clinical spectrum of SARS-CoV-2 infections ranges from asymptomatic to severe symptoms of respiratory failure. ${ }^{3}$ In addition, patients admitted to trauma emergency departments may be asymptomatic or unable to report symptoms due to the severity of trauma. If infected patients were taken for a surgical procedure without adequate precautions for respiratory transmission, the probability of contamination of healthcare professionals and even other patients in the anesthetic recovery room would be very high. Ideally, the use of personal protective equipment and other precautions for SARS-CoV-2 are recommended in all cases of patients undergoing surgical procedures during the COVID-19 pandemic, in order to minimize any chance of transmission. However, resource limitations are an issue to consider in the context of developing countries such as Brazil. Therefore, methods to diagnose suspected cases are essential for the appropriate allocation of equipment, materials, and human resources.

The use of chest CT as a method for diagnosing SARSCoV-2 infection is based on protocols published at institutions 
across the world ${ }^{2,4,10-12}$ and on recommendations from the American College of Surgeons. ${ }^{15} \mathrm{Ai}$ et al. ${ }^{2}$ reported a series of 1,014 patients who underwent chest CT and RT-PCR as the gold standard for detecting SARS-CoV-2 infection. A total of $97 \%$ of patients with positive RT-PCR also had tomographic findings compatible with COVID-19, primarily showing ground-glass opacities. Tomography is a method available in trauma centers and could allow immediate diagnosis of trauma patients with need of surgical intervention. Specific tests for the detection of SARS-CoV-2, when available, require an analysis period longer than a scan. This period of analysis is also dependent on the number of tests awaiting analysis, which indicates that during the peak of the pandemic, the delay in result could be even greater. In the scenario of emergency surgeries, such as those for trauma that require prompt intervention, the assessment of risk of concurrent infection by SARS-CoV-2 also needs to be immediate. This allows efficient allocation of human and material resources, as well as preparation of the healthcare team, including use of adequate personal protective equipment, such as for orotracheal intubation.

In our study, among the 5,017 trauma patients seen in the emergency department, 352 (7.02\%) underwent chest CT. The indication for tomography was mostly due to the trauma mechanism itself, with only $27.84 \%$ of the exams indicated as part of the COVID-19 screening protocol. Among all chest CT scans performed, nine $(2.56 \%)$ presented findings compatible with COVID-19 infection, and one patient (asymptomatic) confirmed infection with RT-PCR testing.

Our institution's experience evidenced an important number of trauma cases in a scenario of a disease pandemic (1) without defined treatment to the present date, (2) which can be asymptomatic, (3) with high transmissibility rates, and (4) with diagnosing exams that show a significant number of false negatives and require a relatively long time for analysis. In our sample, the detection of nine suspected cases for COVID-19 through the use of chest tomography allowed the adoption of measures to minimize the viral transmission to the team and other patients. Although confirmation with RT-PCR occurred in only one case in our sample, the possibility of identifying suspected cases prior to surgical procedures could justify the tomography protocol, as it allows for adequate allocation of resources and minimization of viral transmission.

\section{ConcLusion}

The use of chest CT to screen suspected cases of COVID-19 in the context of trauma surgery, although still requiring further validation, remains an important tool for this purpose.

\section{Clinical Significance}

Developing countries often face low availability of funding in healthcare, especially during times of socioeconomic and political crisis. The COVID-19 pandemic has led to the need to improve allocation of resources in healthcare and screening of COVID-19 suspected patients, with the goal of minimizing viral transmission and the inevitable impact of the pandemic on the quality of patient care delivered.

\section{OrCID}

Camila R Guetter $\odot$ https://orcid.org/0000-0002-7918-4580

Rebeca T lurkiewiecz ๑ https://orcid.org/0000-0001-5878-0781

Matheus S Evangelista ๑ https://orcid.org/0000-0002-0445-3854

Gabriel M Nogueira ๑ https://orcid.org/0000-0001-7120-5431

Silvania K Pimentel ๑ https://orcid.org/0000-0002-4232-4279

Fabio Henrique De Carvalho ๑ https://orcid.org/0000-0002-0719-4624

\section{References}

1. World Health Organization [Internet]. WHO Director-General's opening remarks at the media briefing on COVID-19; 2020 [cited 2020]. Available from: https://www.who.int/dg/speeches/detail/ who-director-general-s-opening-remarks-at-the-media-briefingon-covid-19--11-march-2020.

2. AiT, Yang Z, Hou H, et al. Correlation of chest CT and RT-PCR testing in coronavirus disease 2019 (COVID-19) in China: a report of 1014 cases. Radiology 2020;296(2):E32-E40. DOI: 10.1148/radiol.2020200642

3. Cascella M, Rajnik M, Cuomo A, et al. Features, evaluation and treatment coronavirus (COVID-19). 2020. In: StatPearls [Internet]. Treasure Island (FL): StatPearls Publishing; 2020.

4. Shah A, Walkoff LA, Kuzo RS, et al. The utility of chest $C T$ and RT-PCR screening of asymptomatic patients for SARS-CoV-2 (COVID-19) prior to semi-urgent or urgent hospital procedures. Infect Control Hosp Epidemiol 2020;41(12):1375-1377. DOI: 10.1017/ice.2020.331

5. World Health Organization [Internet]. Global Health Observatory Visualizations:Injuries and Violence [cited 2020]. Available from:https:// apps.who.int/gho/data/node.wrapper.INJURIESVIOLENCE?lang=en.

6. World Health Organization [Internet]. The top 10 causes of death [cited 2020]. Available from: https://www.who.int/news-room/factsheets/detail/the-top-10-causes-of-death.

7. Chu $H$, Reid G, Sack $A$, et al. Changes in burn referrals and injuries during Covid-19. Burns 2020;46(6):1469-1470. DOI: 10.1016/j. burns.2020.06.018

8. Murphy T, Akehurst H, Mutimer J. Impact of the 2020 COVID-19 pandemic on the workload of the orthopaedic service in a busy UK district general hospital. Injury 2020;51(10):2142-2147. DOI: 10.1016/j. injury.2020.07.001

9. Cook Childrens Checkup Newsroom [Internet]. Spike in severe child abuse cases likely result of COVID-19; 2020 [cited 2020]. Available from:https://www.checkupnewsroom.com/spike-in-severe-childabuse-cases-likely-result-of-covid-19\%.

10. Gong Y, Cao X, Mei W, et al. Anesthesia considerations and infection precautions for trauma and acute care cases during the COVID-19 pandemic: recommendations from a task force of the Chinese Society of Anesthesiology. Anesth Analg 2020;131(2):326-334. doi: 10.1213/ ANE. 0000000000004913

11. Lei J, Li J, Li X, et al. CT imaging of the 2019 novel coronavirus (2019-nCoV) pneumonia. Radiology 2020;295(1):18. DOI: $10.1148 /$ radiol.2020200236

12. De Mauro D, Rovere G, Smimmo A, et al. COVID-19 pandemic: management of patients affected by SARS-CoV-2 in Rome COVID hospital 2 trauma centre and safety of our surgical team. Int Orthop 2020:44(12):1-5. DOI: 10.1007/s00264-020-04715-6

13. Martins Filho EL, Mazepa MM, Guetter CR, et al. The role of computerized tomography in penetrating abdominal trauma. Rev Col Bras Cir 2018;45(1):e1348. DOI: 10.1590/0100-6991e-20181348

14. Chung M, Bernheim A, Mei X, et al. CT imaging features of 2019 novel coronavirus (2019-nCoV). Radiology 2020;295(1):202-207. DOI: $10.1148 /$ radiol.2020200230

15. American College of Surgeons [Internet]. Clinical Issues and Guidance; 2020 [cited 2020]. Available from:https://www.facs.org/covid-19/ clinical-guidance. 